\title{
The Effect of Emotional Capital on Job Satisfaction and Life Satisfaction: A Research on Basketball Players in Women's Super League in Turkey
}

\author{
${ }^{1}$ Cafer Şafak Eyel", ${ }^{1}$ Gülşah Akkaya \\ ${ }^{1}$ Graduate School of Social Sciences, Bahçeşehir University, Istanbul, Turkey.
}

Submitted 06 April 2020; Accepted in final form 03 June 2020.

\begin{abstract}
Background. Emotional competencies of individuals are evaluated as a form of capital today. Emotional capital has gained prominence in literature in the last decades. In this regard, qualitative and quantitative studies on emotional capital concept have been conducted. Objectives. The purpose of this study is to analyses the effect of emotional capital on job satisfaction and life satisfaction in terms of women basketball players in Turkey. Methods. The research method of this study is descriptive. The statistical population consisted of 135 women basketball players who were reached via using convenience sampling method. Survey was conducted on athletes between $6^{\text {th }}$ October, 2019 and 30th November, 2019. Emotional Capital Inventory developed by Newman et al. (2015), Job Satisfaction Scale developed by Brayfield and Rothe (1951), shortened by Yoon and Thye (2002), and Life Satisfaction Scale developed by Diener et al. (1985) was used for data collection. SPSS-22 computer program was used in data analysis. The internal consistencies of the questionnaires were obtained by Cronbach's which were 0.81, 0.81 and 0.83 , respectively. After exploratory factor analysis conducted on emotional capital inventory, seven factors were found as social awareness, self-management, self-awareness, self-reliance, relationship management, adaptability, and apathy. Results. The analysis of data revealed that self-reliance factor of emotional capital has significant and positive effect on job satisfaction, and self-management and personal awareness factors of emotional capital have significant and positive effects on life satisfaction. Conclusion. Finally, it can be concluded that emotional capital has partial effect on both job satisfaction and life satisfaction of women basketball players in Turkey's Super League.
\end{abstract}

KEYWORDS: Emotion, Capital, Emotional Capital, Job Satisfaction, Life Satisfaction, Basketball, Women's Basketball, Athlete

\section{INTRODUCTION}

In recent years, women's basketball faced significant changes and become one of the most popular sports in the world. Thousands of professional women's athletes work and play in different leagues all around the world. Professional athletes are sometimes relocating to other cities and countries and adopting to different living situations while expected to perform their best at all times. Therefore, being a professional athlete requires physical, mental and emotional efforts $(1,2)$.
Emotional capital (EC) affects the well-being of athletes and sport organizations and it has a tremendous impact on athletes' behaviours. EC is a type of intelligence that enables athletes to focus on behaviour and attitudes which helps them to perform at their highest level. Self-efficacy, self-confidence, self-motivation, optimism and flexibility are the components of EC which help athletes to control themselves, manage their emotions and reach their goals (2). Self-efficacy, optimism and resilience are

*. Corresponding Author:

Cafer Şafak Eyel, Assistant Professor

E-mail: safakeyel@gmail.com 
the elements of positive psychology. These elements help individuals cope with difficulties, give them determination to continue and strengthen their confidence in being successful when faced with unexpected challenges (3). EC can help individuals reduce their stress and their emotional exhaustion (4). It can also help in relieving the stress that athletes face before major competitions or games, give them a competitive advantage and enhancement in their performance. Athletes' abilities of flexibility and adaptability into changing conditions, are essential for them for encouragement of their creativity and to succeed. Athletes who can adapt to changing environments build up resilience that pushes them for self-development and this kind of resilience not only help athletes improve their on-court performance, but also utilizes athletes' brand names and encourages them to be open about possible business opportunities (2). In this context, a new concept in literature but gaining significance, EC has been studied (5-9) and within the scope of this study, it was aimed to examine the effect of EC on job satisfaction and life satisfaction in women basketball players.

$\mathrm{EC}$ is the independent variable in this study and the concept is gaining importance not only in our country but in many countries around the world. With the studies that have been done in foreign literature in the past years, the foundation of EC concept has been getting established. There are only few studies on the relation of EC with other concepts and its effect on different concepts (5-9). Furthermore, the study has great significance since the effect of women basketball players' EC on their job satisfactions and life satisfactions would be determined. Additionally, the research will contribute to the concept of $\mathrm{EC}$ and to the literature in theory of its relations to job satisfaction and life satisfaction.

Emotional Capital. Jackson (1959) embedded psychology and theology in the subject of grief and when he defined the function of religion, he mentioned of EC for the first time (10). Via using Bourdieu's (1986) social capital theory (11), Nowotny (1981) theorized EC for the first time with the work on Austrian women's lives in public (12). Nowotny (1981) defined EC as the skills and assets that have emotional value and also as knowledge, relations and contacts (12). According to Allatt (1993) EC is composed of emotional assets and skills such as love and affection, expenditure of time, attention, concern and care (13). Gendron (2004) states that EC is the inventory of emotional competencies that are inherent to the individual, useful and essential for cognitive, social, personal and economic growth (14).

Furthermore, it can be discussed EC is a form of strategic assets that help individuals to be successful in their jobs and it affects individuals' positive emotions like achievement, belonging, involvement, and also it has a positive effect on the relationship of individuals boosting their performance (15). The role of EC has changed through the generations. First generation used EC to suppress the emotions that they could feel in order to maintain their existence. Second generation was trapped in an emotional maturity gap that existed in between their pre-school childhood and puberty, and rarely had the chance to develop their emotional skills. Moreover, third generation were the people who cared for elderly, build their own lives, families and careers, and they mastered in their emotional skills (16).

Bourdieu (1986) who has significant studies on social capital concept believed that without understanding his key theoretical concepts that are the "habitus" (ingrained tendencies) and the "field", it would be hard to comprehend the concept of EC (11). Past experiences, gender and class shape the character of the individual; create individual habitus and this habitus is a situation that is open to change and endless. The other key concept "field" consists of set of regulations, rules and values that produce and change behaviour and attitude. In addition, considering all of these, EC is built with encountering experiences, exposure and application (17).

Gendron (2004) mentioned that EC has distinct attributes about emotional competencies, and the concepts of emotional intelligence and emotional competencies have important impacts on personal, economic and social lives of individuals, therefore these concepts should be considered as a form of capital (14). Emotional labour includes the daily emotional display of employees. EC is composed by skills and tendencies which can be build up by emotional labour display practices under certain circumstances (18). Control of emotions may determine the social status of individuals. Further, emotional control plays an important role in accumulating EC and it can boost individuals' social lives (19).

Job Satisfaction. Job satisfaction can be defined as the feeling of satisfaction, happiness and fulfilment that individuals get from their jobs (20). Hoppock (1935) has done the first extensive study on the concept of job satisfaction and in his studies, he has explored this concept with efficiency and performance notions together (21). Locke (1976) states job satisfaction as positive or pleasurable emotional state that an employer feels after reassessing his work experiences. Furthermore, job satisfaction or dissatisfaction is relevant to how a job is perceived and how much it is valued by an employer. Locke suggests the common dimensions of job satisfaction as job, wage, promotional possibilities, work conditions, benefits of the job, supervision and working relations (22). According to Thiagaraj and Thangaswamy (2015), job satisfaction indicates the degree of meeting the expectations of employees towards the job and organization, and describes the attitude of the employee towards the job (23). Spector (1997) puts the feelings of the employee when appraising all the work experience into the centre of job satisfaction and 
highlights the level of like or dislike feeling that the employee has about the job (24).

In the study conducted by Liu et al. (2015), the relations between EC, job satisfaction and organizational citizenship were examined, and it was expressed that there are positive relations between positive emotions of the employees and their job satisfactions. As the result of the study, it was determined that personal EC has significant and positive effects on job satisfaction and organizational citizenship (6). Spector and Fox (2002) explored that positive emotions felt in the workplace have positive effect on job satisfaction and lead to increase in organizational commitment (25). Kiani et al. (2016) mentioned that there is positive relation between selfawareness and job satisfaction. Individuals who improve their self-awareness could manage their emotions much easier under stress or pressure, and have job satisfaction (26). Empowering individuals in their jobs boosts self-confidence and this creates job satisfaction and high level of productivity in the workplace (27). Empathy builds up trust among employees and brings them closer. Certainly, it increases the productivity and job satisfaction of the employees (28). Moreover, various researches demonstrated that there is positive relation between emotional intelligence and job satisfaction (29-31). Based on these findings, to investigate the relation between EC and job satisfaction, this hypothesis statement was formed:

"H1: Women basketball players' emotional capital has significant and positive effect on their job satisfaction".

Life Satisfaction. Life satisfaction concept is also dramatically associated with emotions like it was in job satisfaction (32). The terms of life satisfaction and happiness express similar meanings and they are substitutable for each other (33). Haybron (2011) states that individuals who say they are pleased and content with their lives, are in fact happy with their lives (34). Life satisfaction is an essential part of wellbeing and consists of cognitive/judgmental process of well-being. This process is about the general evaluation of the individuals' life quality according to some criteria they chose. The judgement of the satisfaction depends on the comparison of individuals' existing circumstances with the suitable standards (35). Diener (1984) categorized life satisfaction into three categories. In the first category, virtue and holiness are attributed to life satisfaction. Secondly, evaluation of individuals' life qualities, and the factors affecting these were examined. In the last category, it is stated that depending on the moment, life satisfaction can be affected by individual's emotional state in that moment (36).

Emotional reactions of the employees can change depending on their daily moods and emotional states. These changes influence all emotions of the employees about their jobs and behaviours displayed in the workplace (37). Taheri and Rezayi (2016) emphasize the importance of EC especially for organizations and daily lives of individuals, and mention that $\mathrm{EC}$ has a special place among other capital forms such as social, human and cultural capitals which are complimentary to each other (38). Zhou and Lin (2016) state that there is positive effect of adaptability on life satisfaction (39). Moreover, there is positive relation between selfesteem and life satisfaction, and self-esteem plays an important role in building up life satisfaction (40). Emotions have important influence on people's life satisfactions. These could increase people's emotional awareness and the sense of belonging into a group or team, thus can improve people's life satisfaction (41). In addition, various studies indicate that there is positive relation between emotional intelligence and life satisfaction (7, 41-46). Based on these findings, to investigate the relationship between EC and life satisfaction, this hypothesis statement was formed:

“H2: Women basketball players' emotional capital has significant and positive effect on their life satisfaction.

\section{MATERIALS AND METHODS}

Participants. The universe of this study is composed by basketball players in Women's Super League in Turkey. There are totally 168 licensed Turkish and foreign women basketball players in the super league. After getting the required permissions from Turkish Basketball Federation for the research, the researchers visited all of the basketball clubs in the league. Thus, survey forms were filled by basketball players before their match meetings. In this regard, totally 135 Turkish and foreign women basketball players attended to the research, and 33 players cannot be reached due to some reasons such as injury and day off. Survey questionnaire was conducted on players between the dates of September $6^{\text {th }}, 2019$ and November $30^{\text {th }}$ 2019. Demographical features of participant were reflected in Table 1.

\begin{tabular}{lcc}
\multicolumn{3}{c}{ Table 1. Demographical Features of Sample Group } \\
\hline & $\mathbf{N}$ & $\%$ \\
\hline $\begin{array}{l}\text { Player status } \\
\text { Turkish }\end{array}$ & $\mathbf{9 1}$ & $\mathbf{6 7 . 4}$ \\
$\quad$ Foreigner & $\mathbf{4 8}$ & $\mathbf{3 2 . 6}$ \\
Age group & & \\
$17-22$ & $\mathbf{4 8}$ & $\mathbf{3 5 . 6}$ \\
$23-27$ & $\mathbf{5 1}$ & $\mathbf{3 7 . 8}$ \\
28 and above & $\mathbf{3 6}$ & $\mathbf{2 6 . 6}$ \\
Marital status & & \\
$\quad$ Single & $\mathbf{1 2 0}$ & $\mathbf{8 8 . 9}$ \\
$\quad$ Married & $\mathbf{1 5}$ & $\mathbf{1 1 . 1}$ \\
Education status & & \\
$\quad$ High school degree & $\mathbf{7 6}$ & $\mathbf{5 6 . 3}$ \\
Bachelor's degree & $\mathbf{4 6}$ & $\mathbf{3 4 . 1}$ \\
$\quad$ Graduate degree & $\mathbf{1 3}$ & $\mathbf{9 . 6}$ \\
Position & & \\
$\quad$ Point guard & $\mathbf{2 8}$ & $\mathbf{2 0 . 7}$ \\
Shooting guard & $\mathbf{2 7}$ & $\mathbf{2 0 . 0}$ \\
\hline
\end{tabular}

Measurement Instruments, Validation and Reliability. Within the scope of this research, survey 
technique was used as data collection tool, and a survey questionnaire was prepared and conducted. The answers given by women basketball players for the survey questionnaire was analysed via Statistical Package for Social Sciences (SPSS) 22 computer program. The survey questionnaire has four parts as personal information form, EC inventory, job satisfaction scale and life satisfaction scale. In personal information form, there are questions about player status, age group, marital status, educational status, position, and monthly income.

EC Inventory was developed by Newman and Purse (2007) with 77-statements (47), then shortened by Newman et al. (2015) into 30-statements (48). The scale has five dimensions as self-awareness, social awareness, self-management, adaptability and relationship management. The statements are measured via 5-point Likert scale. EC Inventory was adapted into Turkish language by Tutcu (2018) (7). In the research, as the result of explanatory factor analysis conducted for EC Inventory, 7 factors were determined. Besides the five dimensions of the original scale, 2 other factors as self-reliance and apathy were emerged. Eyel and Vatansever-Durmaz (2019) also determined self-reliance in their study (5). Moreover, the statements under apathy factor are about being cold and remaining aloof. Márquez et al. (2006) discussed apathy is among social competences (49). In factor analysis, KMO value of 0.78 indicates that sample group is sufficient to conduct factor analysis. Furthermore, Bartlett Sphericity Test results (ChiSquare $=1218.05 ; \mathrm{df}=276 ; \mathrm{P}=0.00)$ demonstrate that the scale is convenient to make the factor analysis on it. Total explained variance of the scale is $65.78 \%$. Reliability of social awareness is 0.80 ; of selfmanagement is 0.76 ; of self-awareness is .82; of selfreliance is 0.79 ; of relationship management is 0.69 ; of adaptability is 0.59 ; and of apathy is 0.50 . In this respect, it can be said that social awareness, selfmanagement, self-awareness and self-reliance have high-degree of reliability; and relationship management, adaptability and apathy have sufficient degree of reliability. Furthermore, the reliability of the scale is in high degree with 0.81 .

Job Satisfaction Scale was developed by Brayfield and Rothe (1951) (50), and shortened by Yoon and Thye (2002) into 5-statements (51). The scale has only one dimension, and the statements were measured via 5-point Likert scale. Job Satisfaction Scale was adapted into Turkish language by Kusluvan and Kusluvan (2005) (52). In the research, as the result of explanatory factor analysis conducted for Job Satisfaction Scale, only one factor was determined. In factor analysis, KMO value of .83 indicates that sample group is sufficient to conduct factor analysis. Furthermore, Bartlett Sphericity Test results (ChiSquare $=330.16 ; \mathrm{df}=10 ; \mathrm{P}=0.00)$ demonstrate that the scale is convenient to make the factor analysis on it. Total explained variance of the scale is $63.38 \%$. Reliability of the scale is high with 0.81 .

Life Satisfaction Scale was developed by Diener et al. (1985) with 5-statements (33). The scale has only one dimension, and the statements were measured via 5-point Likert scale. Life Satisfaction Scale was adapted into Turkish language by Yetim (1991) (53). In the research, as the result of explanatory factor analysis conducted for Life Satisfaction Scale, only one factor was determined. In factor analysis, KMO value of 0.85 indicates that sample group is sufficient to conduct factor analysis. Furthermore, Bartlett Sphericity Test results (Chi-Square $=274.57$; $\mathrm{df}=10$; $\mathrm{P}=0.00$ ) demonstrate that the scale is convenient to make the factor analysis on it. Total explained variance of the scale is $62.96 \%$. Reliability of the scale is high with 0.84 .

\section{RESULTS}

Multiple linear regression analyses were made to test the research hypotheses. The result of multiple linear regression analysis in order to test the hypothesis of 'H1: Women basketball players' emotional capital has significant and positive effect on their job satisfaction" was reflected in Table 2. In regression analysis, it was found that adjusted $\mathrm{R}^{2}$ is $15.40 \%$, Fvalue is 4.49 and p-value is 0.000 , that means the regression model is statistically significant. According to the results, $15.40 \%$ of job satisfaction is explained by self-reliance $\left(\mathrm{p}_{\text {self-reliance }}=0.001\right)$, and self-reliance has positive and significant effect on job satisfaction $\left(\beta_{\text {self-reliance }}=0.326\right)$. In this regard, "H1: Women basketball players' emotional capital has significant and positive effect on their job satisfaction" was partially accepted.

Table 2. The Effect of EC Factors on Job Satisfaction

\begin{tabular}{|c|c|c|c|c|c|c|}
\hline Dependent Variable: Job Satisfaction & Beta & T-Value & Sig. & Adj. R2 & F-Value & Sig. \\
\hline Social awareness & -0.054 & -0.581 & 0.562 & 15.40 & 4.49 & 0.000 \\
\hline Self-management & 0.134 & 1.466 & 0.145 & 15.40 & 4.49 & 0.000 \\
\hline Self-awareness & 0.131 & 1.324 & 0.188 & 15.40 & 4.49 & 0.000 \\
\hline Self-reliance & 0.326 & 3.265 & 0.001 & 15.40 & 4.49 & 0.000 \\
\hline Relationship management & 0.083 & 1.008 & 0.315 & 15.40 & 4.49 & 0.000 \\
\hline Adaptability & -0.115 & -1.277 & 0.204 & 15.40 & 4.49 & 0.000 \\
\hline Apathy & 0.137 & 1.668 & 0.098 & 15.40 & 4.49 & 0.000 \\
\hline
\end{tabular}

Moreover, the result of multiple linear regression analysis in order to test the hypothesis of "H2: Women basketball players' emotional capital has significant and positive effect on their life satisfaction" was 
reflected in Table 3. In regression analysis, it was found that adjusted $\mathrm{R}^{2}$ is $14.60 \%$, F-value is 4.267 and p-value is 0.000 that means the regression model is statistically significant. According to the results, $14.60 \%$ of life satisfaction is explained by selfmanagement ( $\left.\mathrm{p}_{\text {self-management }}=0.004\right)$ and selfawareness $\left(p_{\text {self-awareness }}=0.024\right)$, and self-management and self-awareness have positive and significant effects on life satisfaction $\left(\beta_{\text {self-management }}=0.267 ; \beta_{\text {self- }}\right.$ awareness $=0.228$ ). In this regard, "H2: Women basketball players' emotional capital has significant and positive effect on their life satisfaction" was partially accepted.

Table 3. The effect of EC on Life Satisfaction

\begin{tabular}{|c|c|c|c|c|c|c|}
\hline Dependent Variable: Life Satisfaction & Beta & T-Value & Sig. & Adj. R2 & F-value & Sig. \\
\hline Social awareness & -0.160 & -1.731 & 0.086 & 14.60 & 4.267 & 0.000 \\
\hline Self-management & 0.267 & 2.910 & 0.004 & 14.60 & 4.267 & 0.000 \\
\hline Self-awareness & 0.228 & 2.280 & 0.024 & 14.60 & 4.267 & 0.000 \\
\hline Self-reliance & 0.103 & 0.030 & 0.305 & 14.60 & 4.267 & 0.000 \\
\hline Relationship management & -0.078 & -0.943 & 0.348 & 14.60 & 4.267 & 0.000 \\
\hline Adaptability & -0.104 & -1.147 & 0.253 & 14.60 & 4.267 & 0.000 \\
\hline Apathy & 0.058 & 0.707 & 0.481 & 14.60 & 4.267 & 0.000 \\
\hline
\end{tabular}

\section{DISCUSSION}

In this study, data was gathered by 135 women basketball players in Women's Super League in Turkey in order to determine the effect of EC on job satisfaction and life satisfaction. In the literature, there are only a few quantitative previous study about the effect of EC on job satisfaction $(6,7)$. Moreover, there is only one study about the effect of EC on life satisfaction in literature (7). Therefore, studies on emotional intelligence which is closely related to EC were used in order to comment the findings of this study, since dimensions of EC are similar to the dimensions of emotional intelligence.

As the result of multiple linear regression analyses conducted to determine whether there is effect of women basketball players' EC on their job satisfaction, the finding that self-reliance factor of EC has positive and significant effect on job satisfaction was reached. Self-reliance could increase personal performance, and feature taking initiative and leadership attributes of basketball players on the court. Thus, basketball players who have high self-reliance and believe to display good performance on the court, could have high job satisfaction. In this regard, it can be said that EC has a partial effect on job satisfaction. This finding is coherent to the findings of previous studies investigating the relation between job satisfaction and emotional intelligence that forms the basis of EC $(6,7,29-31)$. Effective subjects in terms of job satisfaction can be divided into two groups as external factors such as features of organization, society and culture, and internal factors such as emotions, exciting mood, and personality traits (54). Interpersonal feelings and intrapersonal emotion can control negative feelings and emotion and improve the individuals' performances. In this regard, better performance leads to increase in job satisfaction. People who have high emotional intelligence, have higher job satisfaction, since these people can control hopelessness and stress well (55).

As the result of multiple linear regression analyses conducted to determine whether there is effect of women basketball players' EC on their life satisfaction, the finding that self-management and selfawareness factors of EC have positive and significant effect on life satisfaction was reached. Selfmanagement is the ability of an individual to manage own emotions and life, and it could provide elite professional sportswomen to adapt into another city and satisfy with the life. Self-awareness is about being aware of own skills and abilities in elite level and selfassuredness, and it can be evaluated that basketball players who have high self-awareness with high monthly income, could have high life satisfaction. In this respect, it can be said that EC has a partial effect on life satisfaction. This finding is coherent to the findings of previous studies investigating the relation between life satisfaction and emotional intelligence that forms the basis of EC $(7,41-46)$. People who have high emotional intelligence, have higher life satisfaction, because job satisfaction affects life satisfaction positively and less job stress affects job satisfaction in positive direction (55). It can be said that life satisfaction is characterised by emotions, and it is related with the feelings of happiness / sadness, excitement / anxiety, activation / boredom, selfembellishment / self-deprecation, and inclusiveness / marginality (56).

\section{CONCLUSION}

The results of this research indicated that there is partial effect of EC on job satisfaction and life satisfaction. In terms of the effect of EC on job satisfaction, only self-reliance has positive and significant effect on job satisfaction. Moreover, in terms of the effect of EC on life satisfaction, selfmanagement and self-awareness have positive and significant effect on life satisfaction. And it can be said that the findings of the research is coherent with the findings of previous studies.

For this research, survey questionnaire was used as data collection tool, and the gathered data was limited with the answers of basketball players for the survey. The scope of the study was limited with only women basketball players in Super League in 
Turkey. Moreover, the study was limited with EC, job satisfaction and life satisfaction in terms of the topic. The primary data collected via survey questionnaire was gathered in a certain period of time, and the data involves only women basketball players in Turkish Super League playing between the dates of October $6^{\text {th }}, 2019$ and November $30^{\text {th }}$, 2019. Thus, it is possible to reach into different findings in studies that would be made in different seasons.

For further studies, it could be recommended to make similar researches on men basketball players, youth basketball players, and also on various team sports such as football and volleyball, since such studies would be important to increase the generalizability of the findings reached in this study. Furthermore, EC, job satisfaction and life satisfaction of athletes would be compared via making comparative studies that would be conducted both in Turkey and other countries. Moreover, the relation of EC with some other concepts such as individual competitiveness, individual innovativeness, organizational commitment, organizational citizenship and etc. would be researched.

\section{APPLICABLE REMARKS}

- EC has an important role in athletes and sport organizations to reach into desired performance and to succeed, because it was found in this study that EC of athletes influences their job satisfaction and life satisfaction. In this regard, sport organizations can make some practices to increase athletes' self-reliance, self-management and selfawareness abilities.

- Job satisfaction is so important for every employee and athlete to enjoy the job and also the life, and to reach into the best performance. Thus, sport organizations should organize technical staff and athletes effectively to get the highest job satisfaction.

- Life satisfaction is also so significant for everyone. In terms of basketball players, it can be said that sometimes athletes could have difficulties to adapt into local conditions of the city where the sport organization is located. Therefore, technical staff of the sport organizations should pay attention to the personality traits, emotional and mental competences and EC formation of players when selecting and employing them.

\section{REFERENCES}

1. Moesch K, Kentta G, Kleinert J, Quignon-Fleuret C, Cecil S, Bertollo M. FEPSAC position statement: Mental health disorders in elite athletes and models of service provision. Psychol Sport Exerc. 2018(38):61-71. doi: 10.1016/j.psychsport.2018.05.013

2. Ratten V. Athletes as entrepreneurs: the role of social capital and leadership ability. Int J Entrepreneurship Small Business. 2015;25(4):442-455. doi: 10.1504/IJESB.2015.070217

3. Luthans F, Avey JB, Avolio BJ, Norman SM, Combs GM. Psychological capital development: Toward a microintervention. J Organiz Behav. 2006;27(3):387-393. doi: 10.1002/job.373

4. Walumbwa FO, Luthans F, Avey JB, Oke A. Retracted: Authentically leading groups: The mediating role of collective psychological capital and trust. J Organiz Behav. 2009;32(1):4-24. doi: 10.1002/job.653

5. Eyel CŞ, Vatansever-Durmaz IB. The effect of emotional capital on individual innovativeness: A research on Bahcesehir university business administration undergraduate students. Procedia Computer Sci. 2019(158):680687. doi: $10.1016 /$ j.procs.2019.09.103

6. Liu CC, Chen SY, Liao CH. The relationships among emotional capital, job satisfaction and organizational citizenship behavior: a cross-level analysis. Chiao Da Manage Rev. 2015;35(1):1-24.

7. Tutcu A. Duygusal sermayenin iş ve yaşam doyumu üzerine etkisine ilişkin duyuşsal iyilik algısının aracılık etkisi [doctoral dissertation]. Gaziantep, Turkey: Hasan Kalyoncu Üniversites; 2018.

8. Ay G. Duygusal sermayenin işten ayrılma niyeti ve özdeşleşme üzerine etkisinde psikolojik dayanıklılığın aracılık etkisi [doctoral dissertation]. Gaziantep, Turkey: Hasan Kalyoncu Üniversitesi; 2018.

9. Piri S, Pishghadam R, Dixon LQ, ., Rasekh ZE. Predictors of L2 achievement: Testing a model based on EFL learners' emotional, social, and cultural capitals. Issue Educat Res. 2018;28(3):737-755. doi: 10.1515/iral-20170132

10. Jackson EN. Grief and religion. In The meaning of death, H Feifel (Eds.). New York: McGraw-Hill; 1959.

11. Bourdieu P. The forms of capital. In Handbook of theory and research for the sociology of education, J Richardson (Eds.). CT: Greenwood; 1986. 241-258 p.

12. Nowotny H. Austria: Women in public life. In Access to power: Cross-national studies of women and elites, CF Epstein, RL Coser (Eds.). London: George Allen \& Unwin; 1981.

13. Allatt P. Becoming privileged: the role of family processes. In Youth and inequality, I Bates, G Riseborough (Eds.). Buckingham: Open University Press; 1993.

14. Gendron B. Why emotional capital matters in education and in labour? Towards an optimal exploitation of human capital and knowledge management. In Les cahiers de la maison des sciences economiques, No:113. Paris: Universite Pantheon-Sorbonne; 2004. 
15. Newman M. Emotional capitalists. England: Jossey Bass; 2008.

16. Bodovski K. Childhood and education in the United States of America and Russia. U.S.A.: Emerald Publishing Limited; 2019 Jan. 63-71 p.

17. Ward J, McMurray R. The dark side of emotional labour. New York: Routledge; 2016.

18. Andrew Y. "I"m strong within myself': Gender, class and emotional capital in childcare. British J Sociol Educat. 2013;36(5):651-668. doi: 10.1080/01425692.2013.835711

19. Froyum CM. The reproduction of inequalities through emotional capital: The case of socializing low-income black girls. Qualitative Sociol. 2009;33(1):37-54. doi: 10.1007/s11133-009-9141-5

20. Collie R, Shapka J, Perry N. School climate and social-emotional learning: Predicting teacher stress, job satisfaction, and teacher efficacy. J Educat Psychol. 2012;104(4):1189-1204. doi: 10.1037/a0029356

21. Hoppock R. Job satisfaction. USA: Harper; 1935.

22. A. LE. The nature and causes of job satisfaction. In Handbook of industrial and organizational psychology, MD Dunette (Eds.). Chicago: Rand McNally; 1976.

23. Thiagaraj D, Thangaswamy A. Theoretical concept of job satisfaction - A study. Int J Res Granthaalayah. 2017;5(6):464-470.

24. Spector PE. Job satisfaction: Application, assessment, causes and consequences. California: Sage Publications Inc; 1997.

25. Spector PE, Fox S. An emotion-centered model of voluntary work behavior: Some parallels between counterproductive work behavior (CWB) and organizational citizenship behavior (OCB). Human Resource Manage Rev. 2002(12):269-292. doi: 10.1016/S1053-4822(02)00049-9

26. Kiani S, Iftikhar L, Ahmed F. Relationship between self awareness and job satisfaction among male and female government teachers. J Appl Environ Biologic Sci. 2016;6(2):96-101.

27. Elnaga AA, Imran A. The impact of employee empowerment on job satisfaction. American J Res Communicat. 2014;2(1):13-26.

28. Singh P. Employees' use of empathy to improve their job behaviour. Int Business Economic Res J. 2014;13(3):599610. doi: 10.19030/iber.v13i3.8597

29. Kahn WA. Psychological conditions of personal engagement and disengagement at work. Academy Manage J. 1990;33(4):692-724. doi: 10.2307/256287

30. Abraham R. The role of job control as a moderator of emotional dissonance and emotional intelligence-outcome relationships. J Psychol. 2000;134(2):169-184. doi: 10.1080/00223980009600860 pmid: 10766109

31. Suleman Q, Syed MA, Mahmood Z, Hussain I. Correlating emotional intelligence with job satisfaction: Evidence from a cross-sectional study among secondary school heads in Khyber Pakhtunkhwa, Pakistan. Front Psychol. 2020;11:240. doi: 10.3389/fpsyg.2020.00240 pmid: 32231604

32. Judge TA, Locke EA, Durham CC, Kluger AN. Dispositional effects on job and life satisfaction: the role of core evaluations. J Appl Psychol. 1998;83(1):17-34. doi: 10.1037/0021-9010.83.1.17 pmid: 9494439

33. Veenhoven R. Freedom and happiness: A comparative study in 46 nations in the early 1990's. In culture and subjective wellbeing, E Diener, EM Suh (Eds.). Cambridge: MIT Press; 2000.

34. Haybron DM. Taking the satisfaction (and the life) out of life satisfaction. Philosophical Explorat. 2011;14(3):249262. doi: 10.1080/13869795.2011.594959

35. Diener E, Emmons RA, Larsen RJ, Griffin S. The satisfaction with life scale. J Pers Assess. 1985;49(1):71-75. doi: 10.1207/s15327752jpa4901_13 pmid: 16367493

36. Diener E. Subjective well-being. Psychol Bull. 1984;95(3):542-575. pmid: 6399758

37. Weiss HM, Cropanzano R. Affective events theory: a theoretical discussion of the structure, cases and consequences of affective experiences at work. Res Organizat Behav. 1996;18:1-74.

38. Taheri HM, Rezayi S. Study of emotional capital (feelings of happiness and empowerment) and its role on the development of organizational goals Pars Jame Jam civil company. Scinzer J Humanities. 2016;2(3):16-19. doi: 10.21634/SJH.2.3.1619

39. Zhou M, Lin W. Adaptability and life satisfaction: The moderating role of social support. Front Psychol. 2016;7:1134. doi: 10.3389/fpsyg.2016.01134 pmid: 27516753

40. Moksnes UK, Espnes GA. Self-esteem and life satisfaction in adolescents-gender and age as potential moderators. Qual Life Res. 2013;22(10):2921-2928. doi: 10.1007/s11136-013-0427-4 pmid: 23661225

41. Zou T, Su Y, Wang Y. Examining relationships between social capital, emotion experience and life satisfaction for sustainable community. Sustainabilit. 2018(10):2651. doi: 10.3390/su10082651

42. Palmer B, Donaldson C, Stough C. Emotional intelligence and life satisfaction. Personal Individual Differenc. 2002(33):1091-1100. doi: 10.1016/S0191-8869(01)00215-X

43. Furnham A, Petrides KV. Trait emotional intelligence and happiness. Social Behav Personal. 2003;31(8):815-824. doi: $10.2224 / \mathrm{sbp} .2003 .31 .8 .815$ 
44. Lopez-Zafra E, Ramos-Alvarez MM, El Ghoudani K, Luque-Reca O, Augusto-Landa JM, Zarhbouch B, et al. Social support and emotional intelligence as protective resources for well-being in moroccan adolescents. Front Psychol. 2019;10:1529. doi: 10.3389/fpsyg.2019.01529 pmid: 31354568

45. Szczesniak M, Tulecka M. Family functioning and life satisfaction: The mediatory role of emotional intelligence. Psychol Res Behav Manag. 2020;13:223-232. doi: 10.2147/PRBM.S240898 pmid: 32184683

46. Extreme rN, Sánchez-Álvarez N, Rey L. Pathways between ability emotional intelligence and subjective wellbeing: Bridging links through cognitive emotion regulation strategies. Sustainabil. 2020(12). doi: $10.3390 /$ su 12052111

47. Newman M, Purse J. Emotional capital report - technical manual. Melbourne: RocheMartin Institute; 2007.

48. Newman M, Purse J, Smith K, Broderick J. Assessing emotional intelligence in leaders and organisations: Reliability and validity of the emotional capital report (ECR). Australa J Organisation Psychol. 2015;8(6):1-15. doi: 10.1017/orp.2015.5

49. Márquez PGO, Martín RP, Brackett MA. Relating emotional intelligence to social competence and academic achievement in high school students. Psicothema. 2006;18:118-123.

50. Brayfield AH, Rothe HF. An index of job satisfaction. J Appl Psychol. 1951;35(5):307-311. doi: 10.1037/h0055617

51. Yoon J, Thye SR. A dual process model of organizationalcommitment: job satisfaction and organizationalsupport. Work Occupation. 2002;29(1):97-124. doi: 10.1177/0730888402029001005

52. Kuşluvan Z, Kuşluvan S. Otel işletmelerinde iş ve işletme ile ilgili faktörlerin işgören tatminiüzerindeki görece etkisi: Nevşehir örneği. Anatolia Turizm Araştırmaları Dergisi. 2005;16(2):183-203.

53. Yetim Ü. Kişisel projelerin organizasyonu ve örüntüsü açısından yaşam doyumu [doctoral dissertation]. Izmir, Turkey: Ege Üniversitesi; 1991.

54. Tett RP, Meyer JP. Job satisfaction, organizational commitment turnover, path analyses based on meta-analytic findings. Personal Psychol. 1993;46(3):259-294. doi: 10.1111/j.1744-6570.1993.tb00874.x

55. Moradi M, Honari H, Naghshbandi S, Jabari N, Azarpira G. The relationship between emotional intelligence and job satisfaction among coaches in premier under-20 football league. Int J Academic Res Business Soc Sci. 2012;2(6).

56. Albinson CB, Petrie TA. Cognitive appraisals, stress and coping: Preinjury and postinjury factors influencing psychological adjustment tos port injury. J Sport Rehabilit. 2003;12(4):306-322. doi: 10.1123/jsr.12.4.306 